\title{
Analysis the Effect of Money Supply andThird-Party Funds to the Inflation Rate through Gross Domestic Product in Indonesia Period 2008-2017
}

\author{
Anas Iswanto Anwar', Asma Inawahyuni², Sri Undai Nurbayani ${ }^{3}$ \\ \{aianwar@fe.unhas.ac.id ${ }^{1}$,asmawahyuni25@gmail.com², sri.undai@gmail.com ${ }^{3}$ \} \\ Faculty of Economics and Business, Hasanuddin University, Makassar, Indonesia. ${ }^{1-3}$
}

\begin{abstract}
The objective of this research is to determine the effect of money supply and third-party funds to the inflation rate through Gross Domestic Product (GDP) in Indonesia. The type of data is secondary data. This research used time series data from 2008 to 2017 from various valid data source.The data then were analyzed by multiple regressionswith Two-Stage Least Square (2SLS) approach processed byEviews 9.0.According to resultsanalysis of this study, there is a positive and significant effect between money supply and third-party funds to GDP directly. Partially, it is found that money supply has no significant effect to inflation through GDP and Third-party funds have negative and significant effect to inflation through GDP.
\end{abstract}

Keywords:

Money Supply, Third-Party Funds, Inflation, Gross Domestic Product

Article Received: 18 October 2020, Revised: 3 November 2020, Accepted: 24 December 2020

\section{Introduction}

The success of economic development in one country can be measured by economic growth. Increasing economic growth is one indicator of success in a country, stable economic growth or tends to increase indicates the success of the state government in improving the country's economy. For Indonesia as one of the developing countries, economic development is the main instrument for achieving national ideals. Economic growth is the process by which a nation is increasing output per capita in the long run.

Arsyad (2010) stated that economic growth is an increase in GDP regardless population growth factor and changes in economic structure. The economy is always the most important concern because if a country's economy is in an unstable condition it will cause economic problems such as low economic growth, increasing unemployment, and high inflation rates. But economic growth also has an important role in the development of a country, namely to encourage an increase in national income, an increase in the human development index, increase employment and strengthen the country's position in the eyes of the international. Theoritically, there are many factors influencing economic growth both in fiscal and monetary terms.

When viewed from the monetary sector, Bank Indonesia as the holder of monetary authority in Indonesia has a large role in the determination of monetary policies that will be implemented. Monetary policy is an essential part of macroeconomic policy. Monetary policy is a policy from central bankto control monetary quantities, such as the money supply, base money, and bank loans, as well as interest rates to achieve desired economic growth.

The variables involved in monetary policy itself are related to one another, and it is probable that there will be a trade off in its realization. In its implementation, the expected economic development is the maintenance of macro stability, such as increasing real output which is marked by increasing economic growth. Monetary policy is intended to support the achievement of macroeconomic targets, such as high economic 
growth, price stability, equitable development, and balance of payments balance (Iswardono, 1997).

The inflation rate is one indicator of macroeconomic stability often the center of attention for economic observers in particular and society in general. The rising inflation rate is at least a reflection of the economic turmoil in a country. High inflation is certainly a thing that is very detrimental to the economy of a country. Various studies have shown that in third world countries, poor economic conditions and tend to be less profitable have spurred high inflation rates, which in turn will be disastrous for the community, especially for those with low incomes. People become less eager to work, save, or invest and produce because prices increase rapidly. One of several factors that can influence the formation of inflation is the addition of the money supply and third-party funds.

The problem of the money supply is a very important macroeconomic indicator. This indicator has causal factors and has a severe negative impact on the economy if it is not immediately addressed. Variable money supply or money supply is not only an economic variable in general, but also plays a role as a control variable or policy variable or variable that is targeted to achieve certain goals of government policy (Widiastuti 2012). This is because circulating money is often associated with problems with price changes or inflation. Inflation can only occur if there is an increase in the volume of the money supply in the form of currency and demand deposits. The increasing money supply community will increase people's purchasing power so that people tend to increase their consumption through spending. This will cause price increases due to increasing demand from the community, and over time this will trigger inflation (Sipayung, 2013).

Funds collected from public (TPF) turned out to be the largest source of funds most relied on by banks (can reach $80 \%$ - 90\% of all funds managed by banks) (Dendawijaya, 2009). Act Number 10 of 1998 concerning banking also includes the definition of a bank, which is a company that collects funds and distributes those funds to the community to improve people's living standards.

Control of inflation in the economy is very important, so it must get more attention in analyzing economic conditions, especially the effect on GDP. High inflation is not good because it will make people in a country miserable. Conversely, inflation that is too low is also very detrimental to the state, hence the conditions of controlled inflation or reasonable inflation can provide positive conditions and are conducive to the economy of a country. Therefore, authors are interested to conduct a research titled: "Analysis of the Influence of Circulating Money and thirdparty funds on Gross Domestic Product through Inflation in Indonesia for the Period 2008-2017"

\section{Literature Review}

The stability of the monetary system and the banking system are two aspects that are interrelated and determine each other. Banking system stability in general is reflected in the sound condition of the banking system and the operation of the bank intermediary function in mobilizing public deposits to be channeled in the form of loans and other financing to the business world. If this condition is maintained, the process of money circulation and the transmission mechanism of monetary policy in the economy, which mostly takes place through the banking system, can also run well. The stability of the banking system will determine the effectiveness of the implementation of monetary policy (Warjiyo, 2004).

According to Warjiyo (2004), the effectiveness of monetary policy is very instrumental in carrying out the functions of banking as an intermediary institution, and the function of the central bank as a controller of monetary stability. Using a variety of the instruments the central bank functions as an institution of macroeconomic stabilization, and commercial banks from the 
micro-economic side maintain monetary stability. The monetary amount (stock money) can be in the form of money in the narrow sense and in the broad sense, primary money or bank credit.

The amount of money in circulation (JUB) is M1 (money in the narrow sense) which consists of currency and demand deposits, and M2 (money in the broad sense) which consists of M1 plus quasi money. Currency (currencies are money issued by the government and or central bank in the form of paper money or coins. Deposit money is money issued by a commercial bank. Examples of demand deposits are checks, demand deposits. Quasi money includes savings, time deposits, and foreign exchange accounts (Subagyo, 2012). The amount of money available is called the money supply. In an economy that uses commodity money, the money supply is the amount of the commodity and the government controls the money supply (Mankiw, 2012) Definition of money supply or money supply is divided into three terms, namely in the narrow sense, in the broadest sense and in a broader sense.Understanding Money supply in the narrow sense (M1) is the purchasing power that can be directly used for payments that can be expanded and includes payment instruments that approach money, for example time deposits and savings deposits at banks or can also be dictated fish as currency added with demand deposits (Boediono, 2008). Just as the definition of money in the narrowest sense is currency, the demand deposit here only covers the balance of the newspaper / current account owned by the general public which is kept in the bank, while the balance of the government owned bank account at the bank or central bank is not included in the definition of demand deposits.

The money supply in the broad sense (M2) is also called monetary liquidity. Broad money in the broad sense (M2) is interpreted as M1 coupled with community time deposits and savings balances for banks, because the development of M2 also affects the development of prices, production and economic conditions in general (Boediono, 2008). There is no definition of M2 that is generally applicable to all countries, because this is typical of each country based on consideration. The definition of money supply in the broadest sense is M3, which includes all time deposits and large, small, rupiah or foreign currency savings accounts owned by residents in banks or non-bank financial institutions. All time deposits and savings balances are called quasi money or quasi money (Boediono, 2008).

The money demand theory developed on the basis of classical flow thought, better known as the Money Quantity Theory, explains the role of money in the economy in general, which was first explained by Irving Fisher in 1911 through The Quantity Theory of Money contained in his book The Purchasing Power of Money. This theory holds that the growth of the money supply has a direct relationship with the increase in general prices (inflation) and the growth of the money supply is the main cause of inflation.

Third party funds are funds obtained from the community, in the sense of the community as individuals, companies, governments, households, cooperatives, foundations, etc. both in rupiah and in foreign currencies (Veithzal, 2007). In most or every bank, this public fund is the largest fund owned by the bank. This is in accordance with the function of the bank as a fund collector from the community. Banks are community services and community financial intermediaries. Banks must always be in the midst of the community so that excess cash flow from the community can be accommodated and channeled to disadvantaged communities. Public trust in the existence of the bank and public confidence that the bank will carry out its financial problems as well as possible, is a condition expected by all banks. Third party funds (demand deposits, savings, and time deposits)are collected by banks through various types of fund products offered to the public(Kuncoro, 2002). 
The inflation rate as an indicator of macroeconomic stability is often the center of attention for economic observers in particular and society in general. The rising inflation rate is at least a reflection of the economic turmoil in a country. High inflation is certainly a thing that is very detrimental to the economy of a country. Various studies have shown that in third world countries, poor economic conditions and tend to be less profitable have spurred high inflation rates, which in turn will be disastrous for the community, especially for those with low incomes. People become less eager to work, save, or invest and produce because prices increase rapidly. Workers who receive fixed income will also be overwhelmed to bear and compensate for prices, it will drop their quality of life and deteriorate over time.

Inflation is an economic phenomenon that is associated with a very broad impact on the macro economy. Inflation is important as its role to influence the mobilization of funds through informal financial institutions. Hera (2000) defined inflation as a constant and persistent increase in price of an economy, so inflation is a situation where there is a sharp price increase that lasts continuously for quite a long time. As the price increases, the value of money falls sharply in proportion to the increase in the price. Not all raising price can cause inflation. The price of each item and service is determined in many ways. In a perfectly competitive market, interactions between buyers and sellers that drive demand and supply can shape prices. Inflation is defined as an increase in the overall price level in an economy (Mankiw, 2012). If inflation occurs continuously, it will result in a decline in overall economic conditions and can disrupt a country's political stability.

Gross domestic product defined as measuring the market value of final goods and services produced by resources that are in a country for a certain period of time, usually one year. GDP can be used to compare several economies at one time.
GDP only covers final goods and services sold to the last user. Reselling goods and services will not be covered in GDP, it is to avoid double counting problems. Double calculations can cause the results of the GDP calculation not to show the actual results, so that in this calculation only one calculation is made for each product.

Economic growth is defined as an increase in GDP regardless the population growth and changes in economic structure. Boediono (2011) states that economic growth is a process to increase output in the long run. Economic growth indicators will be used to seethe economy development of a country in long periods, compared year by year. Economic growth will occur if there is a tendency that occurs from the internal process of the economy. Sadono (2004) stated that a tool for measuring the regional economic achievement is the the growth of economic in that region. Local economy will increase yearly due to the addition of production factors. Furthermore, the number of workforces will also increase, so that local economic growth will potentially advance.

Economic growth can be measured by the growth of Gross Regional Domestic Income based on constant prices. Regional economic growth is indicated by per capita GRDP so it can help to indicate achievement of regional welfare. Economic growth as defined by Simon Kuznets is a long-term increase in the ability of a country to provide more and more types of economic goods to its population, this ability grows in accordance with technological advances, institutional and ideological adjustments it needs (Jhingan, 2008). While Todaro (2006) stated that economic growth as a good process whereby the production capacity of an economy increases over time to produce increasingly large levels of income.

Money supply is determined by monetary policy in the Central Bank, while the amount of money demanded is determined by several factors including the average price level in the economy. The higher the price level, the greater the amount 
of money requested.The Money Quantity Theory explains the role of money in the economy in general which was first explained by Irving Fisher in 1911 through The Quantity Theory of Money contained in his book entitled The Purchasing Power of Money. This theory holds that there is a direct relationship between the growth of the money supply and the increase in the general price (inflation) and the growth in the money supply is the main cause of inflation. Money circulating in the community directly increases purchasing power which then increases the price of goods so that the continuous increase will increase inflation.

The inflation rate is one indicator of macroeconomic stability often the center of attention for economic observers in particular and society in general. The rising inflation rate is at least a reflection of the economic turmoil in a country. High inflation is certainly a thing that is very detrimental to the economy of a country. Inflation can have a negative impact on the economy because the continuous price increase may not be affordable to the public. When inflation occurs, people have to spend more money to get the items they want. Whereas at that time there was a cycle in which the company also experienced lethargy which had a direct impact on the decline of company and labor income (Putong, 2003).

According to Keynes' theory, in the long period, inflation rate rises but economic growth falls (Lubis, 2013). Increasing inflation results in real money values falling as prices rise continuously. If the value of real money is low, purchasing power is also low, thereby reducing the level of consumption of the community;as a result the production will also decline. So that economic growth also decreases reflected in gross domestic product.
Control of inflation in the economy is very important, so it must get more attention in analyzing economic conditions, especially the effect on GDP. High inflation is not good because it will make people in a country miserable. Conversely, inflation that is too low is also very detrimental to the state; hence the conditions of controlled inflation or reasonable inflation can provide positive conditions and are conducive to the economy of a country.

\section{Research Method}

Research This research was carried out by covering all regions of Indonesia. This research used secondary data, such as money supply data, third party funds data, inflation data and GDP data for the period of 2008-2017. The data for all variables to be examined starts from 2008 to 2017; each year quarterly, with the amount of data (n) is 40 periods. This data is collected in a continuous time interval (time series).

The analysis of the data used in this study is the Two-Stages Least Squares (2SLS) analysis model or the two-stage method using the Program Eviews 9.0 Enterprise analysis tool. TwoStages Least Squares analysis model (2SLS) is used to determine whether the independent variables (money supply and third-party funds) partially affect the dependent variable (gross domestic product) through the intervening variable (inflation).

To see the extent to which the factors of money supply and third-party funds influence GDP through inflation in Indonesia, the analysis of the Two-Stages Least Squares (2SLS) model is stated as follows: 


$$
\begin{gathered}
Y 1=f(X 1, X 2,) \\
Y 2=f(Y 1)
\end{gathered}
$$

Functions (1) and (2) are then transformed into linear equations, so that the equation is obtained as follows:

$$
\begin{gathered}
\mathrm{Y} 1=\mathrm{f}(\mathrm{X} 1, \mathrm{X} 2,) \\
\mathrm{Y} 2=\mathrm{f}(\mathrm{X} 1, \mathrm{X} 2, \mathrm{Y} 1)
\end{gathered}
$$

Functions (1) and (2) are then transformed into linear equations, so that the equation is obtained as follows:

$$
\begin{gathered}
\mathrm{eY} 1=\alpha 0 \mathrm{X} 1 \alpha 1 \mathrm{X} 2 \alpha 2 \mathrm{e} \mu 1 \\
\mathrm{Y} 1=\alpha 0+\alpha 1 \ln \mathrm{X} 1+\alpha 2 \ln \mathrm{X} 2+\mu 1 \\
\mathrm{Y} 2=\beta 0 \mathrm{X} 1 \beta 1 \mathrm{X} 2 \beta 1 \mathrm{e} \beta 3 \mathrm{Y} 1+\mu 2 \\
\ln \mathrm{Y} 2=\beta 0+\beta 1 \ln \mathrm{X} 1+\beta 2 \ln \mathrm{X} 2+\beta 3 \mathrm{Y} 1+\mu 2
\end{gathered}
$$

By substituting the equation (5) into equation (6) it will obtain the "reduced form" equation as follows:

$$
\begin{gathered}
\ln \mathrm{Y} 2=\beta 0+\beta 1 \ln \mathrm{X} 1+\beta 2 \ln \mathrm{X} 2+\beta 3(\alpha 0+\alpha 1 \ln \mathrm{X} 1+\alpha 2 \ln \mathrm{X} 2+\mu 1)+\mu 2 \\
\ln \mathrm{Y} 2=\beta 0+\beta 1 \ln \mathrm{X} 1+\beta 2 \ln \mathrm{X} 2+\beta 3 \alpha 0+\beta 3 \alpha 1 \ln \mathrm{X} 1+\beta 3 \alpha 2 \ln \mathrm{X} 2+\beta 3 \mu 1+\mu 2 \\
\ln \mathrm{Y} 2=\beta 0+\beta 3 \alpha 0+\beta 1 \ln \mathrm{X} 1+\beta 3 \alpha 1 \ln \mathrm{X} 1+\beta 2 \ln \mathrm{X} 2+\beta 3 \alpha 2 \ln \mathrm{X} 2+\beta 3 \mu 1+\mu 2 \\
\ln \mathrm{Y} 2=(\beta 0+\beta 3 \alpha 0)+\ln \mathrm{X} 1(\beta 1+\beta 3 \alpha 1)+\ln \mathrm{X} 2(\beta 2+\beta 3 \alpha 2)+\beta 3 \mu 1+\mu 2 \\
\ln \mathrm{Y} 2=\delta 0+\delta 1 \mathrm{X} 1+\delta 2 \mathrm{X} 2+\mu
\end{gathered}
$$

Where:

Y1 = Inflation Rate (Percent)
$\mathrm{Y} 2=$ Gross Domestic Product (Rupiah) $\mathrm{X} 1=$ Amount of Money Supply (Rupiah)

X2 = Third Party Funds (Rupiah) 
$\alpha 0, \beta 0, \delta 0=$ Intercep

$\mu 1, \mu 2=$ Error term

$\delta 0=(\beta 0+\beta 1 \alpha 0)$

$\delta 1=(\alpha 1 \beta 1)$

$\delta 2=(\alpha 2 \beta 1)$

$\alpha 1=$ Effect of the money supply on inflation

$\alpha 2=$ Effect of third-party funds on inflation

$\alpha 1 \beta 1=$ The effect of the money supply on gross domestic product through inflation

$\alpha 2 \beta 1=$ The Effect of third-party funds on gross domestic product through inflation

The test criteria performed on the equation model are using statistical testing, including testing the partial regression coefficient (t test), testing the coefficient of determination (R2) and testing the regression coefficients together $(\mathrm{F}$ test).

\section{Analysis}

Table 1.Results of Estimates of the Effect of Money Supply (X1), Third Party Funds (X2) on Inflation (Y1) and the effect of inflation, the money supply, third party funds on GDP in Indonesia Period 2008 - 2017

\begin{tabular}{lllll}
\hline Variable & $\begin{array}{l}\text { Coeffisient } \\
\text { Regression }\end{array}$ & T-Statistic & Probability & Significancy \\
\hline $\begin{array}{l}\text { Money Supply - } \\
\text { Inflation }\end{array}$ & -0.151973 & -1.604498 & 0.1171 & No Significant \\
$\begin{array}{l}\text { Third Party } \\
\text { Funds - Inflation }\end{array}$ & 0.599994 & 6.748163 & 0.0000 & Significant \\
$\begin{array}{l}\text { Inflation - GDP } \\
\text { Money Supply - }\end{array}$ & 0.122893 & 0.870897 & 0.0000 & Significant \\
GDP & & -38.06672 & 0.0389 & Significant
\end{tabular}




$\begin{array}{lllll}\text { Third Party } & 0.283557 & 2.140654 & 0.0390 & \text { Significant } \\ \text { Funds - GDP } & & & & \end{array}$

R-Squared: 0.991855 Adjusted R-Squared: 0.991414

F-Statistic: $2252.752 \quad$ Prob(F-Statistic): 0.000000

$\mathrm{N}=40$

Source: Secondary data processed

The inflation variable (Y1) has a probability level below five percent which is 0.0000 with a coefficient value of -0.869765 , meaning that each increase in the percentage of inflation by one percent significantly causes a decrease in GDP (Y2) of 0.869765 percent. The variable money supply (X1) has a probability level below five percent which is 0.0389 with a coefficient value of 0.122893 which means that each increase in the percentage of money supply by one percent significantly causes an increase in GDP (Y2) of 0.122893 percent. The variable third party funds
(X2) has a probability level below five percent which is 0.0390 with a coefficient value of 0.283557 , meaning that each increase in the percentage of third-party funds by one percent significantly causes an increase in GDP (Y2) of 0.283557 percent.

To find out the effect of the money supply and third-party funds on GDP through inflation in Indonesia obtained by using a manual count taken from the calculation of the regression results in table 1 multiplied by the regression results in table 2 , the results are as follows:

Table 2.Results of Estimates The direct and indirect effects of the money supply (X1) and third-party funds (X2) on GDP in Indonesia Period 2008 - 2017

\begin{tabular}{llll}
\hline Research Variables & Direct Effects & $\begin{array}{l}\text { Indirect effects } \\
\text { through Inflation }\end{array}$ & Total \\
\hline $\mathrm{X} 1 \mathrm{Y} 2$ & $\begin{array}{l}0.122893 \\
\text { (Significant) }\end{array}$ & 0.132180769 & 0.122893 \\
$\mathrm{X} 2 \mathrm{Y} 2$ & (Not Significant) & \\
& $\begin{array}{l}0.283557 \\
\text { (Significant) }\end{array}$ & $\begin{array}{l}\text {-0.521853781 } \\
\text { (Significant) }\end{array}$ & -0.238296781 \\
\hline
\end{tabular}

Source: Secondary data processed 
Table 2 above explains that the direct effect of the money supply on gross domestic product has a coefficient of 0.122893 , illustrating that every one percent increase in the money supply will increase GDP by 0.122893 percent. It can be concluded that directly the variable money supply has a positive and significant effect on GDP in Indonesia for the period 2008-2017. While the direct effect of third-party funds on gross domestic product has a coefficient of 0.283557 , which illustrates that every one percent increase in third party funds will increase GDP by 0.283557 percent. In sum, the third-party funds variable has a positive and significant effect on GDP in Indonesia for the period 2008-2017 directly.

The table above also explains that the indirect effect of the money supply on gross domestic product through inflation states that the variable is not significant. While the indirect influence of third-party funds on gross domestic product through inflation has a coefficient of 0.521853781 , which illustrates that every one percent increase in third party funds will reduce GDP by 0.521853781 percent, so it means that the third party funds variable has a negative and significant effect on GDP through inflation in Indonesia for the period 2008-2017 indirectly.

Conforming to the results of the estimation and analysis of the data above, further explanation is the implications of the factors that affect GDP in Indonesia. The results of the analysis in question along with the findings from previous studies are as follows:

1. Influence of the Money Supply on GDP in Indonesia

According to the results of research estimation, the variable money supply has a significant effect with a probability value below 5\% which is 0.0389 , and has a positive effect on GDP with a coefficient of 0.122893 . The result showed that every one percent increase in the money supply will increase GDP by $0.122893 \%$. These results are consistent with the initial hypothesis. It is stated that there is a positive and significant relationship between the money supply and GDP. The estimation results are also in line with Tambunan (2015), It is stated that the money supply has a positive influence on gross domestic product.

\section{Effect of Third-Party Funds on GDP in Indonesia}

Analyzing the estimation results, it is known that the third-party funds variable has a significant effect with a probability value below $5 \%$, which is 0.0390 , and has a positive effect on GDP with a coefficient value of 0.283557 . It means that every one percent increase in third party funds will increase GDP by 0.283557 percent. These results are in accordance with the initial hypothesis which states that there is a positive and significant relationship between third party funds and GDP. As it is known that third party funds are the same as savings, it can be said that the estimation results are in line with the research by Utomo (2005) which states that savings have a significant influence on economic growth.

\section{Influence of the Money Circulating on GDP through Inflation in Indonesia}

According to the results of research estimates, the variable money supply does not significantly influence GDP through inflation in Indonesia. This is because people spend their money still in the normal stage so that the increase in inflation is not too large but this can increase economic growth as reflected in the Gross Domestic Product. Increased GDP is also affected more than the increase in productivity in the economic sector. The estimation results are consistent with Tambunan (2015). It is stated that the money supply has a positive influence on gross domestic product.

Money supply variable does not have significant effect on inflation with a probability value above $5 \%$, which is 0.1171 . It can be caused by the amount of active circulationconsists of money in circulation, demand deposits, and quasi 
money. Then the percentage of quasi money consists of domestic time deposits, savings, and foreign exchange deposits is quite large. The value on quasi money is not liquid. So even though the value is high, money supply is not enough to influence the increase of inflation rate. This is consistent with the research conducted by Perlambang (2010), Hartomo (2010), and Sipayung (2013). They stated that the money supply does not significantly influence inflation. However, the estimation results are also not in accordance with Mahendra (2016). He stated that the money supply has a positive effect on inflation.

\section{Effect of Third-Party Funds on GDP through Inflation in Indonesia}

According to the results of the research estimation, the third party funds variable has a significant effect with a probability value below $5 \%$ which is 0.0000 , and negatively affects GDP through inflation in Indonesia with a coefficient value of -0.521853781 which means that every one percent increase in third party funds will reduce GDP through inflation amounting to 0.521853781 percent. This is in line with the previously made hypothesis which states that third party funds have a negative and significant effect on GDP through inflation. Bank will use third party fund to be distributed in real sector activities through lending so that if more and more funds are collected by banks, the bigger ones will be channeled to productive sectors so that it will increase production and consumption, increased production and consumption will tend to increase inflation. Increasing inflation results in real money values falling as prices rise continuously. If the value of real money is low, purchasing power is also low, thereby reducing the level of consumption of the community; as a result the production will also decrease. As a result, economic growth also decreases reflected in gross domestic product. As it is known that third party funds are the same as savings, the estimation results are in line with Utomo (2005) who stated that savings significantly influence economic growth.

Based on the estimation of third party funds variable has a significant effect with a probability value below $5 \%$ which is 0.0000 , and has a positive effect on inflation in Indonesia with a coefficient value of 0.599994 which means that every one percent increase in third party funds is accompanied by an inflation increase of 0.599994 percent. In general, the funds from public will be distributed by bank to fund real sector activities. The more funds collected by banks, the amount of funds to be distributed to productive sectors will even more. Then it will increase production and consumption. Increasing production and consumption in this case will tend to increase inflation.

\section{Conclusion and Suggestion}

According to the research resultsand discussion in advance before, the authors come into conclusions: 1. Directly the money supply has a positive and significant effect on GDP while third party funds have a positive and significant effect on GDP in Indonesia for the period 2008-2017. 2. Indirectly, the money supply does not have a significant effect on GDP through inflation. Whereas third party funds indirectly have a positive and significant effect on GDP through inflation in Indonesia for the period 2008-2017.

According to the results of the research conducted, several suggestions were made: 1 . An increase in the money supply should match the real needs of the community and be adjusted to the inflation target of Bank Indonesia. 2. The money supply must be maintained and intensified so that gross domestic product increases, but the use of the money supply must be more productive in order to increase GDP. 3. Third party funds collected by banks or financial institutions should be maintained in order to provide smooth distribution of credit activities so that they have a positive impact on economic growth in Indonesia. 
5. The Government and Bank Indonesia are advised to be intensive in coordinating as a step to overcome the inflation rate.

\section{References}

[1] Arsyad, Lincolin. 2010. Ekonomi Pembangunan. Yogyakarta: UPP STIM YKPN.

[2] Boediono. 2008. EkonomiMoneter, Edisi 3. BPFE UGM. BPFE, Yogyakarta.

[3] Dendawijaya, Lukman. 2009. ManajemenPerbankan. Ghalia Indonesia. Jakarta. Gujarati,

[4] Hartomo, HarioAji. 2010. PengaruhJumlah Uang Beredar dan KursterhadapInflasi di Indonesia Sebelum dan SesudahKrisis Global 2008. Media Ekonomi, Vol. 18 No. 3 Hal.1-22.

[5] Hera, dkk. 2000. IndikatorindikatorMakroekonomi.

FakultasEkonomi Universitas Indonesia. Jakarta.

[6] Iswardono, SardjonoPermono. 1997. Indonesian Monetary Policy. Journal of Economics FE-UII vol. 3/2 May 191997.

[7] Jhingan. 2008. Ekonomi Pembangunan Perencanaan. Raja Grafindo. Persada. Jakarta.

[8] Kuncoro. 2002. ManajemenPerbankan, Teori dan Aplikasi. PT. IndeksKelompok Gramedia. Jakarta.

[9] Lubis. Ismail Fahmi. 2013. AnalisisHubunganantaraInflasi dan PertumbuhanEkonomi: Kasus Indonesia. QE Journal Vol. 03 No. 01-44.

[10] Mankiw, N. Gregory dan dkk. 2012. PengantarEkonomi Makro. SalembaEmpat. Jakarta.

[11] Perlambang, Heru.2010. AnalisisPengaruhJumlah Uang Beredar, Suku Bunga SBI, Nilai TukarTerhadap Tingkat Inflasi. Media Ekonomi Vol. 19 No. 2 Agustus, Hal. 1-20.

[12] Putong, Iskandar. 2003. PengantarEkonomiMikro dan Makro. Edisikedua. Ghalia Indonesia. Jakarta.
[13] Sadono, Sukirno. 2006. Ekonomi Pembangunan Proses Masalah dan Dasar Kebijakan. CetakanKetiga. PenerbitKencana. Jakarta.

[14] Sipayung, Putri TirtaEnistin, dan Made Kembar Sri Budhi. 2013. Pengaruh PDB, Nilai Tukar dan Jumlah Uang BeredarterhadapInflasi di Indonesia periode 1993-2012. E-JurnalEkonomi Pembangunan Universitas Udayana, Vol. 2 No. 7.

[15] Subagyo, dkk. 2012. Bank dan Lembaga KeuanganLainnya. Yogyakarta: Sekolah Tinggi IlmuEkonomi YKPN.

[16] Tambunan, SelyNovy. 2015. PengaruhJumlah Uang Beredar dan PengeluaranPemerintahterhadapProdukDo mestikBruto (PDB) Indonesia. JomFekon Vol. 2 No.1 Februari. Todaro, Mahendra, A. 2016. AnalisisPengaruhJumlah Uang Beredar, Suku Bunga SBI dan Nilai TukarTerhadapInflasi di Indonesia. JRAKVol. 2 No. 1 Maret Ha. 1-12.

[17] Michael P., Todaro. 2006. Pembangunan Ekonomi di Dunia Ketiga. Erlangga. Jakarta.

[18] Utomo, YudiPrihadi dan Basuki Rahmad. 2005. PengaruhHutangLuar Negeri, Penanaman Modal Asing dan Tabungan DomestikterhadapPertumbuhanEkonomi Indonesia (1976-2000). JurnalEkonomi Pembangunan Vo. 6 No. 1 Juni, 12-25.

[19] Veithzal, Rivai. (2007). Bank and Financial Institute Management. Jakarta: PT. Raja GrafindoPersada.

[20] Warjiyo, Perry. 2004. MekanismetransmisiKebijakanMoneter di Indonesia. Pusat Pendidikan dan StudiKebanksentralan (PPSK). Jakarta.

[21] Widiastuti, Irene Linda. 2012. PengaruhJumlah Uang BeredarterhadapInflasi di Indonesia BulanJanuari 2001-Desember 2011. FakultasEkonomi Universitas Atma Jaya Yogyakarta. 